\title{
Physical condition, longevity, and social performance of Dutch haemophiliacs, 1972-85
}

\author{
C Smit, F R Rosendaal, I Varekamp, A Bröcker-Vriends, H Van Dijck, Th P B M Suurmeijer, E Briët
}

\begin{abstract}
A study was carried out among. haemophiliacs in The Netherlands to evaluate the effect of modern substitution treatment (replacing the missing clotting factors) on medical and social performance. Three questionnaires were sent between 1972 and 1985. The use of prophylactic treatment in the group of patients with severe and moderately severe haemophilia increased from $21 \%(n=242)$ in 1972 to $36 \%(n=559)$ in 1985 . Home treatment programmes increased from $4 \%$ to $53 \%$. Overall mortality was $2 \cdot 1$ times higher than in the general male population, which leads to a calculated life expectancy of 66 years compared with 74 years in the general male population. Severe joint impairment was prominent in the older age groups, reflecting insufficient treatment in the past. A sharp decrease in the use of inpatient and outpatient hospital facilities was observed as well as much less absence from school and work.
\end{abstract}

It is concluded that the high costs of modern substitution treatment are fully justified.

\section{Introduction}

Before modern substitution treatment was introduced at the end of the 1960s haemophilia caused premature death and severe disability at a young age. The possibility of a person with haemophilia enjoying a full social life was non-existent or limited. The availability of clotting factor concentrates and the introduction of home treatment have greatly improved the quality of life of patients with haemophilia and their families. The feelings of optimism that resulted from this development have, however, gradually disappeared with the occurrence of diseases that are associated with transfusion, such as hepatitis and AIDS.

Unlike patients in hospital who receive a few or just one transfusion with full blood or blood components haemophiliacs receive during their life many transfusions of clotting factor VIII or IX, which they lack. This so called substitution or replacement treatment is given on demand (when bleeding occurs) or as a prophylaxis. It is this repeated substitution treatment that makes haemophiliacs so susceptible to diseases associated with transfusion, especially when the clotting factor concentrates are made from large pools of donor blood.

The side effects of transfusion, together with the cost of treating haemophiliacs and the growing pressure on health care budgets, may cause people to question whether the benefits of substitution treatment still outweigh the disadvantages. A few studies only have dealt with this question and they have been limited to small numbers of patients or to one aspect for instance, the introduction of home treatment or employment. Moreover, these studies concerned single treatment networks so that the conclusions may not be generalised. ${ }^{1-6}$

The aim of our study was to evaluate modern haemophilia treatment in The Netherlands. Therefore, we reviewed the medical and social performance of Dutch haemophiliacs by means of questionnaires sent out in 1972, 1978, and 1985.

\section{Methods}

We carried out three postal surveys among Dutch haemophiliacs in 1972, 1978, and 1985. The first was based on a haemophilia questionnaire used by the Children's Orthopedic Hospital in Los Angeles, California. The questionnaire was prestructured (multiple choice) and had some open questions. The standardised questionnaires covered a broad range of aspects of haemophilia-for example, type and severity, number of bleedings, transfusion treatment, treatment regimens, orthopaedic state, hospital admissions, education, disability and employment, insurance, social relations, genetic counselling, and so on. Many items were repeated in the second and third surveys, while questions on some current topics, such as home treatment (second) and infection with HIV (human immunodeficiency virus) (third) were added. Patients or their parents were reached through the Dutch Haemophilia Society, treatment centres, and notices in the press. When necessary the information from the patients' questionnaires was supplemented with data from the haemophilia treatment centres. Cumulative data refer to the one year period directly preceding the mailing of the questionnaires.

Figures on mortality were calculated for the respondents in either one or both of the first two surveys, with follow up extending up to 1 January 1986. These formed a group of 717 patients; none was lost to follow up. Mortality was calculated by life table method and compared with the mortality of a hypothetical cohort of the general male population with a similar age distribution. These and other data for the general male population were provided by the Central Bureau for Statistics ${ }^{8}$ and the Department of Social Affairs and Employment. ${ }^{9}$

Joint impairment for 16 joints was scored as follows: 0 , no impairment of the joint; 1 , some impairment but no daily problems; 2 , impairment with daily problems; 3 , impairment with complete loss of function. The total score ranged from 0 to 48 points.

Of the 935 participants in the 1985 survey 567 (61\%) had also participated in one of the earlier surveys. Of the 376 patients with mild haemophilia in the 1985 survey, $207(55 \%)$ were new participants, in contrast to $91(24 \%)$ and $70(40 \%)$ patients with severe and moderately severe haemophilia respectively. To allow data from the three surveys to be compared we decided

Leiden, PO Box 9600

2300 RC Leiden,

Br.Med f 1989:298:235-8 
to exclude the patients with mild haemophilia from the analysis. We investigated whether a "healthier new patients effect" still existed-that is, whether the patients in the 1985 survey who had not participated in the earlier surveys were healthier than those who had participated before, which would of course lead to an overoptimistic view. As a measure for comparison we used the score on joint impairment, as defined above. Table I shows the score for joint impairment for patients who were new participants and those who also participated in 1972 or 1978 , stratified by age. The observed differences in joint score were small and not significant $(\mathrm{p}<0 \cdot 05)$.

TABLE I-Scores for joint impairment: patients participating for the first time (new) in the 1985 survey compared with those who participated in one of the earlier surveys (old)

\begin{tabular}{|c|c|c|c|c|c|c|}
\hline \multirow[b]{2}{*}{$\begin{array}{l}\text { Age } \\
\text { years }\end{array}$} & \multicolumn{2}{|c|}{$\begin{array}{l}\text { Old patients } \\
(\mathrm{n}=389\end{array}$} & \multicolumn{2}{|c|}{$\begin{array}{c}\text { New patients } \\
(\mathrm{n}=92)\end{array}$} & \multirow{2}{*}{$\begin{array}{c}\text { Difference } \\
\text { of } \\
\text { means }\end{array}$} & \multirow{2}{*}{$\begin{array}{c}95 \% \\
\text { Confidence } \\
\text { interval }\end{array}$} \\
\hline & No & $\begin{array}{l}\text { Mean } \\
\text { score }\end{array}$ & No & $\begin{array}{l}\text { Mean } \\
\text { score }\end{array}$ & & \\
\hline & 86 & & 36 & & $0 \cdot 29$ & -0 \\
\hline $20-34$ & 159 & $5 \cdot 55$ & 27 & 4.52 & 1.03 & -1.01 to 3.08 \\
\hline $35+$ & 144 & $10 \cdot 40$ & 29 & 6.52 & 3.88 & -1.12 to 6.58 \\
\hline
\end{tabular}

Note: The age groups were chosen to form about equal sized subgroups in the "new" patients group. The youngest patients were excluded since the could not have participated in one of the earlier surveys. For all three age groups the differences in the mean joint scores were small and not significan $(\mathrm{p}<0.05)$ as the $95^{\circ}, 0$ confidence interval of the difference enclosed zero.

\section{Results}

Response-The response to the questionnaires was $84 \%$ in 1972 (447 participants), $70 \%$ in 1978 (560 participants), and $81 \%$ in 1985 (935 participants from 1162 questionnaires mailed). With an estimated prevalence of 8.5 per 100000 population and a total population of 14.5 million Dutch we reached more than $90 \%$ of all Dutch haemophiliacs in 1985, and three quarters responded to the survey.

In $1985,801(85 \%)$ respondents had haemophilia A, $132(15 \%)$ haemophilia B, and two patients had a factor VII and factor XIII deficiency, respectively. This distribution was similar in the first two surveys. In $1985,384(40 \%)$ had severe, $175(20 \%)$ moderately severe, and $376(40 \%)$ mild haemophilia; 19 (5\%) patients with severe haemophilia had an inhibitor, and another 12 mentioned that their one time inhibitor had been eradicated.

Treatment-Both prophylactic treatment and home treatment have increased enormously since 1972 (table II) in the group with severe and moderately severe haemophilia. The average number of manifest bleedings decreased from 19 a year in 1972 and 1978 to 13 a year in 1985 , with a corresponding decline in the number of transfusions needed for treatment on demand. For comparison, those with mild haemophilia reported one bleed a year in 1985. In the group with severe and moderately severe haemophilia substitution treatment for $495(89 \%)$ patients consisted of clotting factor concentrates prepared by the Dutch Red Cross blood transfusion services; $35(6 \%)$ of the

TABLE II-Type of treatment given to patients with severe and moderately severe haemophilia. Figures are numbers (and percentages)

\begin{tabular}{lrrr} 
& 1972 & 1978 & 1985 \\
$(\mathrm{n}=242)$ & $(\mathrm{n}=351)$ & $(\mathrm{n}=559)$ \\
\hline Notreatment & $33(14)$ & $34(10)$ & $29(5)$ \\
Treatment on demand & $157(65)$ & $201(57)$ & $329(59)$ \\
Prophylactic treatment & $52(21)$ & $116(33)$ & $201(36)$ \\
Home treatment & $9(4)$ & $88(25)$ & $298(53)$
\end{tabular}

^Those who received no treatment because of no bleedings, the presence of an inhibitor, or inaccessibility of treatment facilities. respondents were treated with commercially produced imported concentrates, whereas 29 received no treatment. The market share of the commercially produced imported concentrates proved somewhat higher in the survey of 1978 but then declined, probably owing to the risk of HIV infection.

Life expectancy-We found an overall mortality (43 deaths) $2 \cdot 1$ times higher than would have occurred in a group of non-haemophiliacs of the same age distribution. This excess mortality in haemophilia leads to a calculated median life expectancy of 66 years (general male population: 74 years), when an equal distribution of excess mortality over age is assumed. Most improvement has been made in severe haemophilia, and now almost equal death rates apply for severe, moderate, and mild haemophilia. Patients with an inhibitor had a far less favourable prognosis, with a risk of death five times higher than the severely affected haemophiliacs without an inhibitor. ${ }^{10}$

$H I V$ - In our latest survey more than a third (134) of all patients with severe haemophilia had been tested for antibodies to HIV compared with $41(23 \%)$ and 40 $(11 \%)$ of the patients with moderately severe and mild haemophilia, respectively. The overall seropositivity was $17 \%$ (36 of 217 ), with the highest prevalence $(21 \%)$ of HIV antibodies among patients with severe haemophilia."

Foint impairment-Looking at the total score of joint impairment in 1985 we saw that $58(15 \%)$ of the patients with severe haemophilia reported no joint damage at all compared with $68(39 \%)$ and $224(60 \%)$ of those with moderately severe and mild haemophilia.

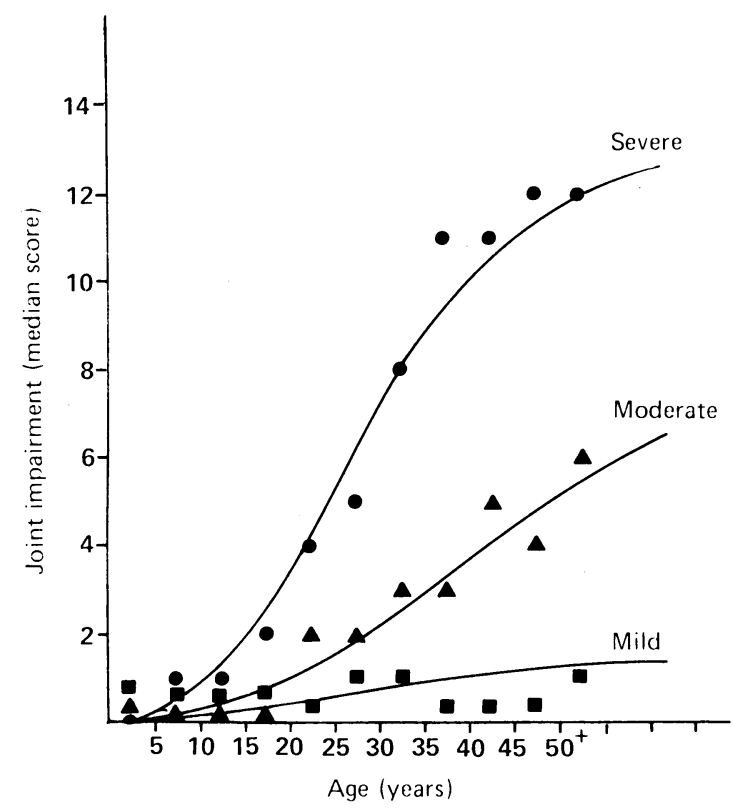

Foint impairment score by age of respondents with severe $(n=384)$, moderately severe $(n=175)$, and mild haemophilia $(n=376)$ in 1985. Median scores were calculated for five year age groups and are shown at the mid-interval point. Patients aged over 50 were combined as " $50+$ "

Almost half (281) of the patients with severe and moderately severe haemophilia had a score of 1 to 7 of a total of 48 points. One in every three patients with severe haemophilia had nine or more points, which implies three joints with complete loss of all function or several joints with minor damage. To illustrate the impact of the severity of haemophilia we calculated in the figure the median score of joint impairment for severe, moderately severe, and mild haemophilia. The median score on joint impairment was highest in the older age groups.

Use of hospital facilities - In 1985 the average use of inpatient hospital facilities was four days per patient a 
year in the group with severe and moderately severe haemophilia compared with one day for the general Dutch male population. In 1972 this difference was still 21 days. In 1972 one out of every two patients needed to go to hospital, in contrast to one out of every four in 1985. For those who went into hospital the average number of days spent in hospital dropped from 49 days in 1972 to 16 days in 1985 , which was near to the national average of 13 days for men (table III).

TABLE III - Use of inpatient hospital facilities for patients with severe and moderately severe haemophilia

\begin{tabular}{lcccc} 
& $\begin{array}{c}1972 \\
(\mathrm{n}=242)\end{array}$ & $\begin{array}{c}1978 \\
(\mathrm{n}=351)\end{array}$ & $\begin{array}{c}1985 \\
(\mathrm{n}=559)\end{array}$ \\
\hline $\begin{array}{l}\text { Average hospital use (number of days } \\
\text { per patient a year) }\end{array}$ & $23(2)^{\star}$ & $10(2)^{\star}$ & $4(1)^{\star}$ \\
$\begin{array}{c}\text { No (\%) of patients requiring } \\
\text { admission to hospital }\end{array}$ & $114(47)$ & $129(37)$ & $126(23)$ \\
$\begin{array}{c}\text { Average duration of admission (number } \\
\text { of days per patient a year) }\end{array}$ & $49(20)^{\star}$ & $26(15)^{\star}$ & $16(13)^{\star}$ \\
\hline
\end{tabular}

^Figures for the general male population.

The number of transfusions performed at home rose from 996 in 1972 to 29680 in 1985 . Therefore, the number of outpatient visits to the hospital decreased substantially.

Social participation-Table IV shows the improvement in social participation, as judged by absence from school and work. The educational level of the survey

TABLE IV-Absence from school and work of patients with severe and moderately severe haemophilia

\begin{tabular}{|c|c|c|c|}
\hline & $\begin{array}{c}1972 \\
(\mathrm{n}=242)\end{array}$ & $\begin{array}{c}1978 \\
(\mathrm{n}=351)\end{array}$ & $\begin{array}{c}1985 \\
(\mathrm{n}=559)\end{array}$ \\
\hline $\begin{array}{l}\text { Average duration of absence from school } \\
\text { due to haemophilia (number of days } \\
\text { per patient a year) }\end{array}$ & 36 & 19 & 9 \\
\hline No of respondents at school & 105 & 163 & 196 \\
\hline $\begin{array}{l}\text { Average duration of sick leave from work } \\
\text { (number of days per patient a year) }\end{array}$ & $32(18)^{\star}$ & $34(18)^{\star}$ & $20(15)^{\star}$ \\
\hline No of respondents with a job & 91 & 114 & 215 \\
\hline
\end{tabular}

^Figures for the general male population; national figures are not available for school absence.

population in 1985 was not different from that of the general male population. For the respondents aged between 15 and 64 years who had finished their education, table $\mathrm{V}$ shows the participation in the national labour force. The number of Dutch men who do not work owing to unemployment or disablement has grown substantially over the past 15 years.

TABLE $\mathrm{v}-$ Participation in the national workforce of respondents aged 15 to 64 years with severe and moderately severe haemophilia

\begin{tabular}{|c|c|c|c|}
\hline & $\begin{array}{c}1972(\mathrm{n}=113) \\
\%\end{array}$ & $\begin{array}{c}1978(\mathrm{n}=168) \\
\%\end{array}$ & $\begin{array}{c}1985(\mathrm{n}=330) \\
\%\end{array}$ \\
\hline No (\%) active & $89(79)(91)^{\star}$ & $116(69)(85)^{\star}$ & $215(65)(77)^{\star}$ \\
\hline $\begin{array}{l}\text { No }(\%) \text { inactive } \\
\text { Relative inactivity ratio } \\
\text { (haemophiliacs to } \\
\text { non-haemophiliacs) }\end{array}$ & $24(21)(9)^{\star}$ & $52(31)(15)^{\star}$ & $115(35)(23)^{\star}$ \\
\hline
\end{tabular}

*Figures for the general Dutch male population. Not included are those respondents who still receive full time education.

Although the same tendency was seen for the haemophiliacs, the difference between the patients and the general male population decreased. This is shown by the relative inactivity ratio which dropped from 2.3 in 1972 to 1.5 in 1985 . In all three surveys unemployment among haemophiliacs was lower than the national average, but the percentage of haemophiliacs with a disablement pension was higher than in the general male population. ${ }^{9}$ Higher disablement figures were found especially in the older age groups, reflecting more severe joint impairment.

\section{Discussion}

In The Netherlands we have no central registry of medical or other data on patients with haemophilia. By means of postal surveys we got an overview of the medical and social circumstances of Dutch haemophiliacs and were able to observe the changes that occurred from 1972 to 1985. Of a possible 1250 patients with haemophilia in The Netherlands we reached 935 patients $(75 \%)$ in our last survey.

The relative mortality in haemophilia is low and indicates a life expectancy that is almost in the normal range. The relative mortality is now the same as that caused by smoking cigarettes. ${ }^{12}$ These results correspond well with recent data from Sweden ${ }^{13}$ and the United States. ${ }^{14}$ It must be feared, however, that these figures will be affected negatively by mortality from infection with HIV and liver disease.

Although measures have been taken to prevent HIV infection, many haemophiliacs were infected before these could be implemented. ${ }^{15}$ A prevalence of seropositive patients here of $17 \%$ is low compared with $50 \%$ in France, ${ }^{16} 53 \%$ in West Germany, ${ }^{17} 39 \%$ in the United Kingdom, ${ }^{18}$ and $80 \%$ in the United States. ${ }^{19}$ It is higher, however, than in Belgium, $4 \%^{20}$ or Finland, $1.5 \%$ (E Ikkala, personal communication). The low numbers of seropositive patients in these two countries and The Netherlands can be explained by the predominant use of plasma products from local unpaid donors.

Many haemophiliacs are still unable to participate fully in employment owing to joint impairment. We expect that in the future this situation will improve as more and more young haemophiliacs grow up with better joints and muscles than the older haemophiliacs did. A much longer observation period will be needed, however, to see if this expectation becomes reality, so that the 1985 level of joint impairment in patients with severe haemophilia will diminish to the level of those with moderately severe haemophilia as shown in the figure. Of course, the number of disabled persons in the workforce will always be dependent on the general economic situation and the attitude of society towards them.

Smith et al pointed out the encouraging results of comprehensive haemophilia care programmes in the United States. They concluded that the properly treated employed patient can generate more money than his treatment costs.' Schimpf and Niederberger showed in a group of German haemophiliacs that the employed patient would be able to make up roughly half the cost of treatment through contributions to the gross national product and pension savings." For The Netherlands we estimate that with an average consumption of 54000 units of factor VIII a year the cost $(\$ 24300)$ is more than the average annual income of a Dutch man (\$21900). The difference in outcome between these studies is caused by the difference in cost per unit of factor VIII in the United States $(\$ 0 \cdot 10-0 \cdot 12)$ and in Europe $(\$ 0 \cdot 40-0 \cdot 50) . .2$ These differences in cost and other marketing strategies make it difficult to make meaningful cost calculations. ${ }^{23}$

Nevertheless, our findings show the improvement of the main medical and social indicators which provide quantitative support for the general impression that the introduction of modern clotting factor concentrates in the late 1960s followed by prophylaxis and home treatment have greatly improved the life expectancy and the quality of life of haemophiliacs and their families. The non-material gains such as less pain and discomfort and an improved social life would justify the cost of modern replacement treatment even in the 
absence of the savings due to fewer admissions to hospital, less absenteeism from work or school, and lower social security payments. It is difficult to judge the success of the treatment without considering the disastrous AIDS epidemic, but the favourable trends shown by our results give us a glimpse of the promises held by the newer products and methods for the treatment of haemophiliacs.

We gratefully acknowledge the enthusiastic participation of the patients with haemophilia and the collaboration of the Dutch haemophilia treatment centres. Dr J Hermans, department of medical statistics, University Hospital Leiden, kindly gave us advice on statistical matters.

The study was supported by grants from Het Praeventiefonds (28-1099) and De Stichting Haemophilia.

1 Smith PS, Keyes NC, Forman EN. Socioeconomic evaluation of a state-funded comprehensive hemophilia-care program. $N$ Engl f Med 1982;306:575-9.

2 Aledort LM. Lessons from hemophilia. N Engl I Med 1982;306:607-8.

3 Lazerson J. Hemophilia home transfusion program: analysis of cost data. f Pediatr 1973;83:623-5.

F Pediatr 1973;83:623-5.
Carter F, Forbes CD, Macfarlane JD, Prentice CRM. Cost of management of patients with haemophilia. Br Med f 1976;ii:465-7.

5 Goldsmith MF. Hemophilia, beaten on one front, is beset on others. $7 \mathrm{AMA}$ 1986;256:3200

6 Stuart J, Forbes CD, Jones P, Lane G, Rizza CR, Wilkes S. Improving prospects for employment of the haemophiliac. BrMed f 1980;280:1169-72. Children's Orthopedic Hospital. A total approach to treatment and rehabilitation: hemophilia survey. Los Angeles, California: Children's Orthopedic Hospital, 1968

8 Central Bureau for Statistics. Statistical yearbook. Den Haag: Staatsuitgeverij,
9 Ministerie van Sociale Zaken en W'erkgelegenheid. Rapportage arbetdsmarkt 1986. Den Haag: MSZW, 1986

10 Rosendaal FR, Smit C, Varekamp I, et al. Mortality and causes of death in Dutch haemophiliacs, 1973-1986. Brf Haematol (in press).

11 Rosendaal FR, Smit C, Varekamp I, Bröcker-Vriends A, Suurmeijer T, Briët E. AIDS and haemophilia: a study among Dutch haemophiliacs on the psychological impact of the AIDS threat, the prevalence of HIV antibodies and the adoption of measures to prevent HIV transmission. Haemostosis 1988:18:73-82.

12 Hammond EC, Horn D. Smoking and death rates: report on 4 months of follow-up of 187783 men. I. Total mortality. FAMA 1958;166:1159-72.

13 Larsson SA. Life expectancy of Swedish haemophiliacs, 1831-1980. Br $\mathcal{J}$ Hoemalol 1985;59:593-602.

14 Johnson RE, Lawrence DN, Evatt BL, et al. Acquired immunodeficiency syndrome among patients attending hemophilia treatment centers and mortality experience of hemophiliacs in the United States. Am f Epidemol

15 Wolfs TFW, Breederveld C, Krone WJA, et al. HIV-antibody seroconversions in Dutch haemophiliacs using heat treated and non heat treated coragulation factor concentrates. Thromb Haem 1988;59:396-9.

16 Allain JP. Prevalence of HTLV-III/LAV antibodies in patients with hemophilia and in their sexual partners in France. $N$ Engl $f$. Med 1986:315:517-8.

17 Erfle V, Hehlmann R, Mellert W, et al. Prevalence of antibodies to HTLV-III in AIDS risk groups in West Germany. Cuncer Res 1986:45 (suppl):4627-9.

18 AIDS Group of the United Kingdom Haemophilia Centre Directors. Prevalence of antibody to HTLV-III in haemophiliacs in the United

19 Goedert JJ, Sarngadharan MG, Eyster ME, et al. Antibodies reactive with human $T$ cell leukemia viruses in the serum of hemophiliacs receiving factor

20 Rouzioux C, Brun-Venizet F, Couroucé AM, et al. Immunoglobulin G antibodies to lymphadenopathy-associated virus in differently treated antibodies to Iymphadenopathy-associated virus in differently t
French and Belgian hemophiliacs. Ann Interm Med 1985:102:476-9.

21 Schimpf $\mathrm{K}$, Niederberger $M$. Cost effectiveness in treatment of severe haemophilia. Haemostasis $1981 ; 10$ (suppl 1):185-7.

22 Hagen PJ. Blood: gift or merchandise. New York: Liss, 1982.

23 Cash JD. Coagulation factor VIII concentrates and the marketplace. Lancet $1988 ; 1: 1270$.

Accepled 27 September 1988 )

MEDICINE AND THE MEDIA

The Times 20 January 1989 and other newspapers

\section{Egg saga rolls on}

An extensive nationwide outbreak of infection by Salmonella enteritidis type 4 had already been taking place in Britain over the past two years when on Saturday 3 December, to the extreme annoyance of the Ministry of Agriculture, Fisheries, and Food, a characteristically unguarded remark by Mrs Currie ("that most of the country's egg production" was infected with salmonella) nudged the egg down the slope of controversy. Later, when the runaway egg crushed her "tall poppy" personality in its path the secretary of the British Egg Producers' Association greeted her resignation as "the best Christmas present egg producers could have had" (The Times, 17 December).

Three days after Mrs Currie's resignation the government also came up with an astonishingly indulgent compensation programme - a $£ 19 \mathrm{~m}$ budget to pay producers for destroying the eggs and laying hens that consumers no longer fancied. Many Conservative MPs said that the aid package was inadequate (The Times, 20 December).

Just as the dust was beginning to settle and the Commons select committee on agriculture was deflecting further consumer flak, along came the listeria threat to TV dinners ("Legal loopholes bring TV danger dinners alert," Daily Mail, 16 January; and "Tesco in safety alert over cook-chill foods," Daily Mail, 17 January). A sensitised press was quick to spot the parallels with the salmonella story: some food producers were not taking sufficient care to keep contaminated raw ingredients away from the pre-cooked chilled meals (just as some manufacturers of poultry feed were failing to keep raw poultry offal from cross contaminating heat treated feed for laying hens). And in both cases the ministry was accused of being tardy in introducing statutory regulations to cope with the problem and of playing down its true size ("Listeria poison risk "is bigger than admitted", Daily Telegraph, 16 January.) Did this lack of vigour in protecting consumers have its roots in Mr MacGregor's revelation (elicited by a question in parliament) that in 1988 the ministry had had at least 37 formal meetings with farmers' representatives but only two with a mainstream food consumers body ("Minister fuels storm over farming bias," Daily Mail, 17 January)?

So, since the early days the rogue egg has gathered speed and weight, and press rumours now suggest that it is on a collision course with the ministry. There is speculation in Westminster that Mrs Thatcher is preparing to parcel out the ministry's functions to the Department of Health and the Department of the Environment ("MacGregor scents trouble in the wind,"Guardian, 19 January). Certainly, the Prime Minister must have been stung by references to the "government's panic £19 m compensation scheme" of which only "a paltry $£ 5$ m" has been taken up. In the Daily Mail (16 January), Paul Johnston described this level of take up as putting Mrs Thatcher in the humiliating posture of "tamely abasing herself to a shameless pressure group." And the same day Sir Richard Body, a Conservative and former chairman of the Commons select committee on agriculture, writing in the
Evening Standard (and generally inveighing against factory farming and subsidised overproduction), said that it was time that the "one-sided Ministry was wound up" and called for a "Department of Food and Health."

On 19 January most papers carried the news that the Minister of Agriculture has finally decided to beef up a newly introduced voluntary code for the egg industry with new laws for feed producers and that he is to review the Food Act, which according to the Institution of Environmental Health Officers is "powerless ... against problems involving cook-chilled products in shops" (Daily Mail, 16 January).

We have yet to see whether these overdue efforts will make it clear that the Ministry of Agriculture, Fisheries, and Food "is not the public affairs branch of the National Farmers' Union" (Guardian, 19 January)but Mrs Thatcher is bound to be keeping a beadier and, in the light of her new environmental stance, a greener eye on the relationship of the ministry with farmers and consumers (Anonymous. All systems green. [Editorial.] The Grocer, 14 January).

But it would be a mistake to overstate the prime ministerial threat to Mr MacGregor. As the political editor of The Times writes today (20 January), Mr MacGregor (previously a highly successful chief secretary to the Treasury) has "contributed the biggest (real) slice of the government's savings in public spending of any department"a projected $£ 1500 \mathrm{~m}$ over four years-by cutting farm subsidies and food mountains. For this he has earned himself the titles of "Mac Scrooge" and "Mac the Knife" in the agricultural press. - JANE DAWSON 